\title{
An Analysis of the Effects of Disaggregated Agricultural Output on Foreign Reserves in Nigeria
}

\author{
Uzoma Chidoka Nnamaka Ph.D ${ }^{\mathbf{1}}$ \& Okidim, Andrew Iboh Ph.D ${ }^{\mathbf{2}}$ \\ ${ }^{1}$ Rivers State Universal Basic Education Board, Port Harcourt, Nigeria \\ ${ }^{2}$ Department of Agricultural and Applied Economics, Rivers State University, Port Harcourt, \\ Nigeria. \\ DOI - http://doi.org/10.37502/IJSMR.2021.4410
}

\begin{abstract}
Agriculture as the largest sector in Nigeria has potentials of providing the country the desired foreign exchange earnings. This study therefore examined the effects of disaggregated agricultural output on foreign reserve in Nigeria for a 39- year time period spanning from 1981 to 2019. Time series data on foreign reserves, crop production, livestock, forestry, fishery and exchange rate were sourced from the Central Bank of Nigeria $(\mathrm{CBN})$ statistical bulletin. The study adopted the econometric techniques of co-integration, error correction mechanism (ECM) technique and granger causality test to analyze the time series data. The Augmented Dickey Fuller stationarity test showed that the variables were stationary at first difference and second difference. The Johansen co-integration test results revealed the existence of a longrun relationship among the variables. The error correction model showed that crop production, livestock, forestry and fishery did not impact significantly on foreign reserve in Nigeria. The coefficient of ECM, which was rightly signed and significant, showed that in the event of shock or disequilibrium, the situation would go back to normal at the speed of 0.23 percent per annum. The granger causality test revealed that crop production and exchange rate had bi-directional causal relationships with foreign reserves while there was a uni-directional relationship between fishing and foreign reserves. The stability tests using the plots of the cumulative sum of recursive residuals (CUSUM) and cumulative sum of squares of recursive residual (CUSUMSQ) confirmed the stability of the model and as such can produce a reliable forecast. Based on these findings, the study recommends amongst others that the federal government should channel part of its ownership of foreign reserve in form of recoveries, grants and bilateral cooperation to crop production in Nigeria as this has potentials of improving the reserve in the economy.
\end{abstract}

Keywords: Agricultural output, foreign reserves, Co-integration, Error Correction Mechanism.

\section{Introduction}

Nigeria occupies about 923,768 square kilometers with about 68 million hectares of arable land, fresh water resources covering about 12.6 million hectares, $960 \mathrm{~km}$ of coastline and lies within the tropics along the gulf of guinea on the western coast of Africa having a highly diversified agro-ecological condition which makes the production of a wide variety of crops, livestock, forestry and fishery products possible (Ewetan et al, 2017). Agriculture has undoubtedly 
remained the foundation of Nigeria's economy that is why Ehui and Tsigas (2013) and Etale and Ayunku (2015) rightly opined that it constitutes one of the most important sectors of the economy. This is why most of the world active but poor live in rural areas and are basically involved in agriculture. The potentials of Agriculture in reforming the social and economic framework of a nation cannot be over emphasized as they include; a source of basic food supply for the nation, a catalyst for industrialization through the provision of industrial raw materials, the expansion of employment opportunities for a larger percentage of its citizenry, contribution to the gross domestic product and the generation of foreign earnings through increasing the export base of the economy. (World Bank 2014, Ishmael 2018, Tuaneh \& Okidim, 2019, Eze et al, 2020). In sum, the contributions of the agricultural sector to the growth of an economy can be grouped into; food production, market contribution, factor contribution and very importantly, foreign exchange contribution Ewetan et al, (2017).

Agriculture had a record of being the principal foreign exchange earner of Nigeria as the nation once had a record of being the world's largest exporter of groundnut, the second largest exporter of cocoa and palm produce and an important exporter of rubber, and cotton in the In the 1960s, (Sekunmade, 2009). Early 1970's saw agricultural exports as a percentage of total exports dropping from about 43 percent to slightly over 7 percent. The decline in agricultural export continued from the mid-1970s to the mid-1980s with a record of 17 percent. It is sad to note that despite Nigeria's rich agricultural resource endowments, the nation still relies on imports to meet its food and agricultural product needs. Nigeria's agricultural imports rose by 12.7 percent from N851.6 billion in 2018 to N959.5 billion in 2019, the highest value ever recorded in the country so far while agricultural exports declined by about 11 percent from N302.2 billion to N269.8 billion during the same period. Agriculture accounted for less than 2 percent of total exports in 2019. This has made Nigeria remain a net food importer as the agricultural trade deficit grew from N549.3 billion in 2018 to N689.7 billion in 2019. In four years, (2016 - 2019), Nigeria's cumulative agricultural imports between 2016 and 2019 stood at N3.35 trillion, four times higher than the agricultural export of N803 billion within the same period. (Oyaniran, 2020).

\section{Nigeria's agricultural trade ( $N^{\prime}$ billions)}

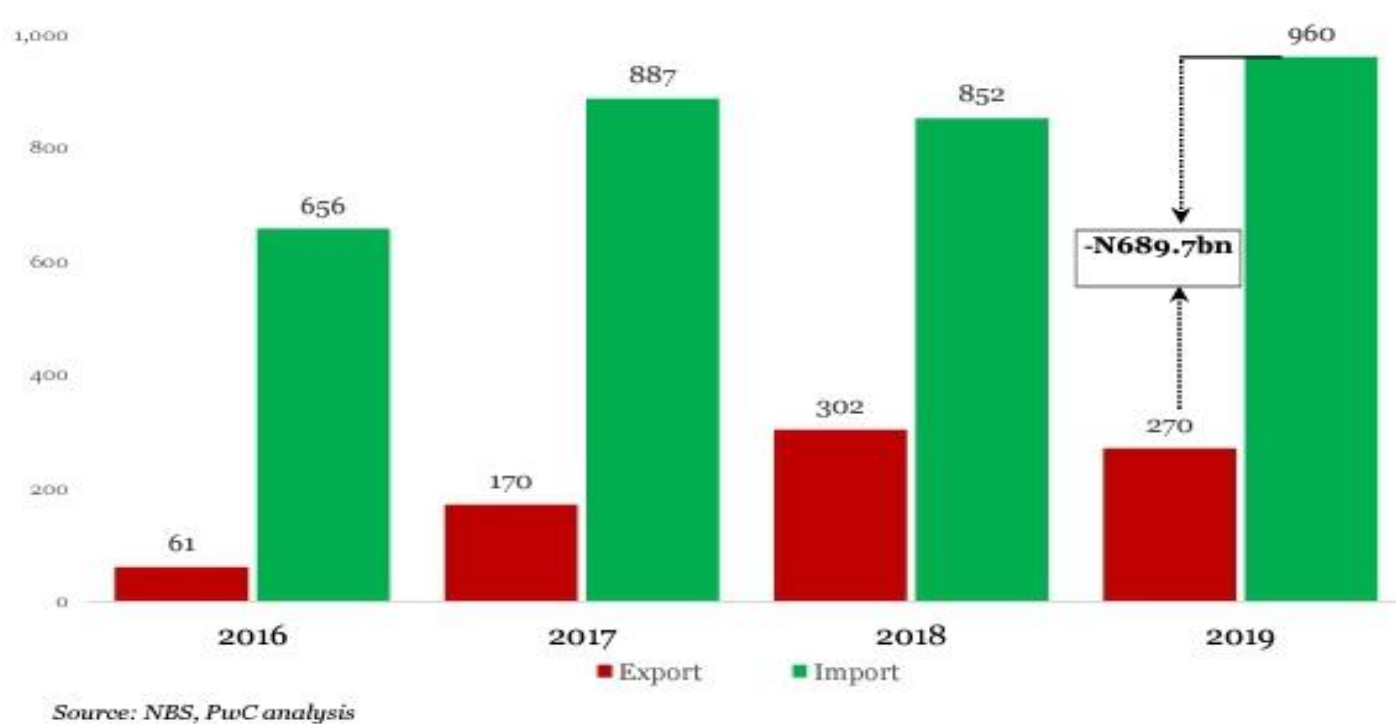

Figure 1: Agricultural Trade in Nigeria 
Several policies and intervention strategies have been initiated by different governments in Nigeria to tackle the poor performance of the agricultural sector and they include: The Agricultural Credit Guarantee Scheme Fund, the River Basin Development Authorities, the National Accelerated Food Production Programme, the Agricultural Development Project, Operation Feed the Nation, the Green Revolution, the National Directorate of Food, the National Agricultural Land Development Authority, Roads and Rural Infrastructure, the National Special Programme for Food Security, Root and Tuber Expansion Project, the National Fadama I and II program, the International Institute for Tropical Agriculture (Ishmael2018, Obayori 2018, Tuaneh \& Okidim, 2019). Furthermore, In August 2019, the government restricted food imports by banning the importation of poultry, pork, beef, eggs, refined vegetable oil and fat, spaghetti, sugar and fruit juice and also closed its land borders with neighboring countries which remarkably reduced illegal cross border trade of agricultural items. Nigeria's agricultural sector has been hurt by several shocks which includes sporadic flooding, Boko Haram insurgencies and conflicts between herdsmen and local farmers. Poor transport infrastructure and services particularly in the rural areas and a neglect of the processing and manufacturing segment of the value and supply chain. To accelerate mechanization in the agricultural sector, the Green Imperative agricultural plan was also introduced in 2020. Ake (1996), Olajide (2012), World Bank 2014, Tuaneh \& Okidim, 2019, Eze et al, 2020 have stressed on agriculture as a regenerative source of foreign exchange earnings. Osabohien \& Osuagwu (2017) further posited that agricultural productivity has the capacity of increasing exports which in turn improves the balance of payment, stabilizes the exchange rate and increases foreign reserves. This is to say that agricultural output has strong potentials of improving foreign reserve in Nigeria. This reserve, alternatively referred to as external or international reserve, consists of official external assets which are controlled by the monetary authorities for direct financing and payment imbalance regulation through exchange market intervention. According to CBN, external reserves are assets held on reserve by a monetary authority in foreign currencies. They include foreign bank notes, deposits, bonds, treasury bills and other government securities. For most African countries, the aggregation of reserves is seen as a protective policy to serve as a form of self-indemnity hastened by high level of world-wide financial and economic instability and the lack of international crisis management (Uzoma et al, 2021). Foreign reserve ownership in Nigeria is categorized into the central bank, the federal government and the federation. The ownership by the central bank arises as the bank receives foreign exchange inflows from the sale of crude oil and other sources of revenue. These proceeds are shared every month in line with the prevalent revenue sharing formula and the constitution. The central bank thereof conducts its monetary policy from the portion of the reserves. The ownership by the federal government consists of funds set aside by the federal government to finance its obligations in which the central bank has no discretion. The funds represent savings, recoveries, grants or bilateral cooperation set aside for specific projects or purposes. Finally, the ownership by federation consists of government's savings of excess proceeds of crude oil, petroleum profit tax and royalty. It has been observed that developing countries typically hold reserves to equal at least three months of imports. The objectives of reserve management in Nigeria amongst others is to provide adequate liquidity to ensure that reserves are available to meet important needs in the economy (CBN, 2021).

It is important to note that despite the possible ability agricultural output has in improving foreign reserves in Nigeria, the level of importation of agricultural product prevalent in the country has constituted a leakage to foreign reserves. This has led to the quest to investigate the 
impact of agricultural output on foreign reserves in Nigeria. The study disaggregated agricultural output into crop production, livestock, forestry and fishing to detangle their individual effects on foreign reserve in Nigeria. The rest of this study is sectioned into literature review, methodology, results and discussions and finally, conclusion and recommendations.

\section{Literature Review}

\section{The Composition of Agricultural Output in Nigeria}

Agriculture is basically about the cultivation of the soil for the growing of crops and raw materials and the rearing of animals to provide food. This is to say that agriculture is made up the following sub-activities: crop production, livestock, fishing and forestry.

\section{Size of the different segment of the agricultural sector}

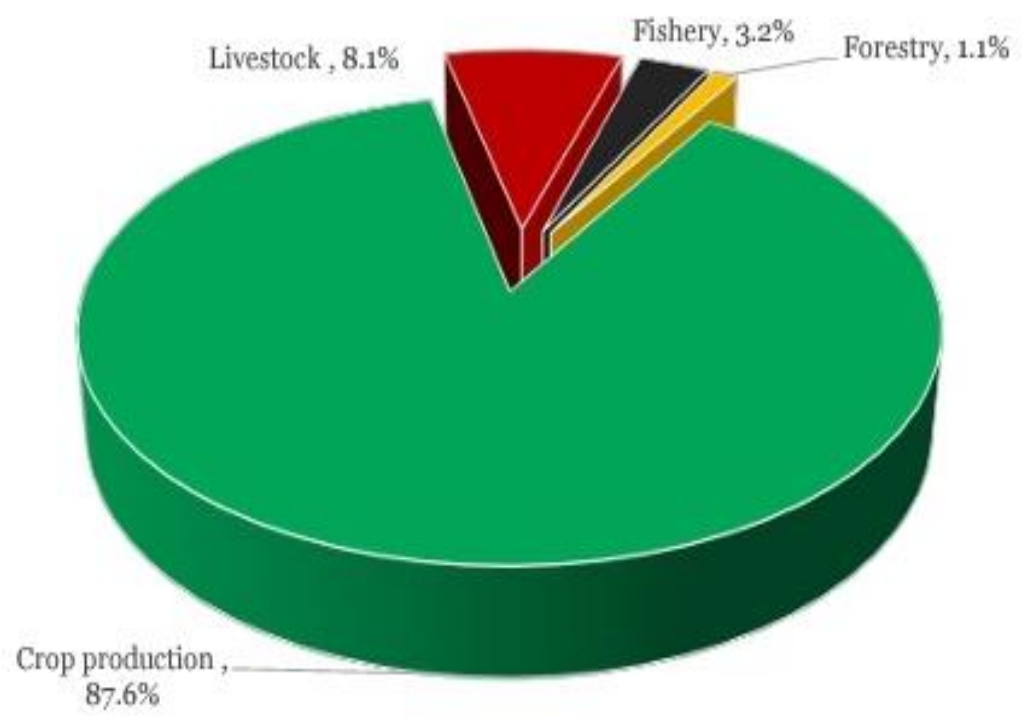

Source: NBS, PwC analysis

Figure 2: Disaggregated Agricultural Output

Figure 2 shows the size of the different segments of agricultural sector as at 2020. From observation, crop production is the largest subsector of agriculture accounting for about 87.6 percent of the sectors output followed by livestock, fishing and forestry with 8.1 percent, 3.2 percent and 1.1 percent contributions respectively. Prior to that time, from 1981 to 2016, crop production also contributed the largest to the sector followed by the livestock.

Fishery and forestry had similar shares over the same period. Crop production recorded its lowest share of 76.37 percent in 1984 and its highest share of 90.16 percent in 2012. Crop production under agriculture, grew from 2.26 percent in 2018 to 2.51 percent in 2019 before dropping to 2.24 percent in 2020 . Livestock production on the other hand, recorded its lowest share of 6.79 percent in 2012 and its highest share of 17.35 percent in 1984. The subsector 
dropped from 0.33 percent in 2018 to 0.16 percent before peaking up to 1.91 percent in 2020 . Furthermore, the contribution of forestry grew to 3.33 percent in 1984 and recorded its lowest value of 1.03 percent in 2016. Forestry dropped from 3.06 percent growth rate in 2018 to 2.59 percent in 2019 and further to 1.62 percent in 2020. Finally, fisheries had its minimum contribution of 1.41 percent in 1994 and recorded its highest of 4.07 percent in 1983. The subsector grew from 1.64 percent in 2018 to 3.33 percent in 2019 before dropping by 0.26 percent in 2020 .

According to the CBN (2016), agricultural activities in the fourth quarter of 2016 were dominated by harvesting of crops. In the southern part of the country, farming activities centered on harvesting of tubers, fruits and vegetables, while farmers in the Northern part engaged in the harvesting of late maturing grains, and pre-planting operations in preparation of dry season planting. Farmers engage in the fattening of cattle and broilers in the livestock and fisheries subsectors respectively, in anticipation of the end of the year sales. The dominant contribution of crop sub-sector could be attributed to the large share of the sector in the disbursement of Agricultural Credit Guarantee Scheme (ACGS) loan, followed by livestock and fisheries subsectors. The annual growth rate of agriculture in 2020 was 16.73 percent as against the growth rate of 16.51 percent in 2019 (NBS, 2021). The sectors overall contribution to GDP in real terms grew from 26.09 percent in 2019 to 26.95 percent in 2020.

\section{Agriculture's contribution to GDP (\%)}

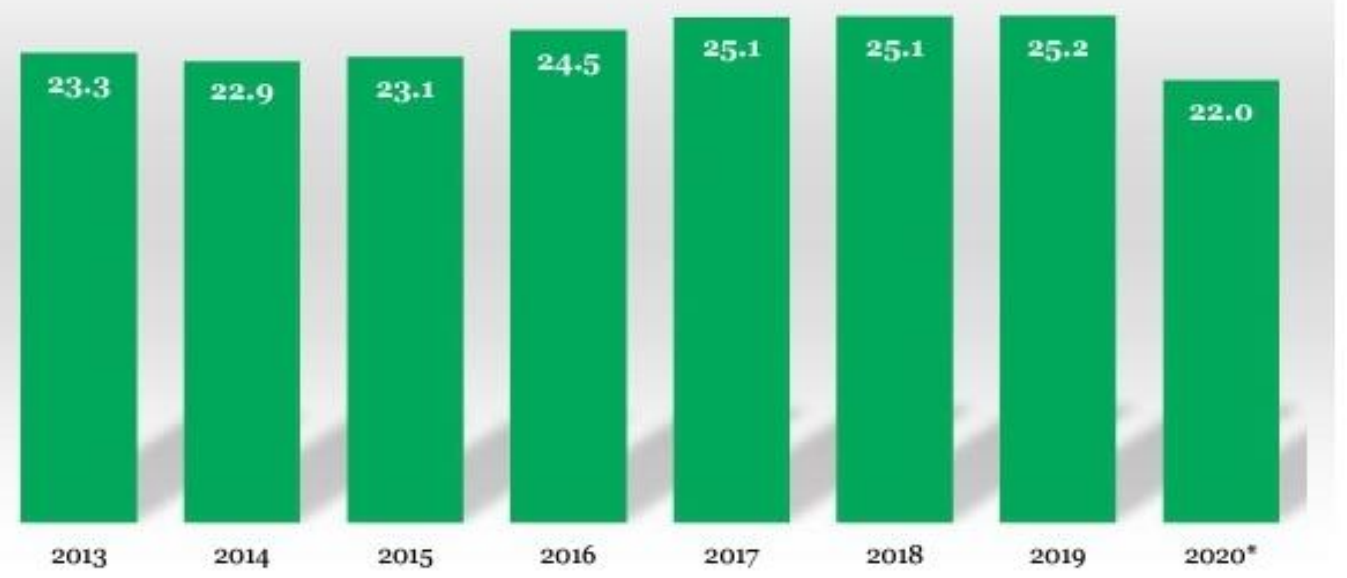

Figure 3: Agricultures Contribution to GDP 


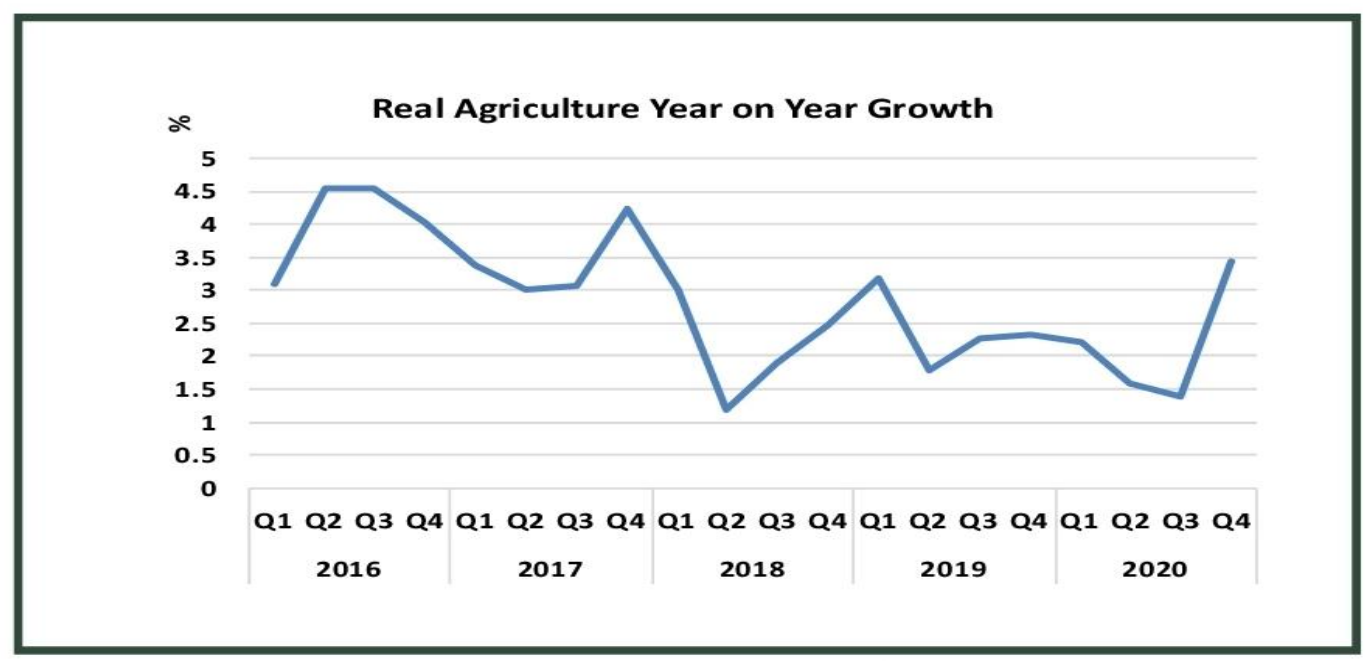

Figure 4: Agricultural Sector Growth Rate (2016Q1 - 2020Q4)

Source: NBS 2021

\section{Empirical Literature}

Over the years, a lot of studies have been carried out on the relationship between agricultural output and various macroeconomic variables. In an extended model of Matsuyama (1992), Chang, et al (2006) showed that agricultural productivity impacted positively on economic growth through revenue generation that dominates the negative growth effect through the comparative advantage.

Aminu \& Anono (2012) examined the contribution of agricultural sector and petroleum sector to the economic growth in Nigeria from 1960 to 2010. The Augmented Dickey-Fuller and Chow breakpoint tests conducted showed the variables to have attained stationarity at first difference and the absence of structural breaks in the period under review. Their findings showed that agricultural sector contributed had a positive impact on the economic growth in Nigeria.

Odetola \& Etumnu (2013) used the growth accounting framework and time series data from 1960 to 2011 to examine the impact of the agricultural sector on economic growth in Nigeria. Their study showed that agricultural sector impacted positively on economic growth in Nigeria. The positive impact of agriculture to economic growth was further affirmed by the causality test where agricultural growth granger caused GDP Growth.

In analyzing the impact of agricultural exports on the macroeconomic performance of Pakistan from 1972 to 2008, Syed et al (2015) found a negative relationship between agricultural export and economic growth. They therefore recommended that the government of Pakistan embark on structural changes by converting its agricultural exports into value added products.

Ewetan et al (2017), using the Johansen maximum likelihood cointegration approach and Vector error correction model, examined the long run relationship between agricultural output and 
economic growth in Nigeria from 1981 to 2014. Their results confirmed a long run relationship between agricultural output and economic growth in Nigeria.

Nelson and Wilberforce (2018) examined the relationship between external reserve and economic growth in Nigeria for the period, 1980 to 2016 using Johansen cointegration, ordinary least square (OLS) and granger causality test. Findings from their study showed that there exists a negative and insignificant relationship between external reserve and agricultural output in Nigeria.

Amao \& Oni (2020) analyzed the relationship between agricultural exports and Gross Domestic Product (GDP) in Nigeria for the period 1960 to 2016. Using the Johansen co- integration and General Method of Moment (GMM) technique, their findings showed that agricultural exports impacted economic growth negatively and insignificantly. Only the beverages and tobacco subsectors were however found to be statistically significant still in a negative direction.

Osuagwu (2020) investigated the interdependence between agricultural productivity and manufacturing industry output in Nigeria for the period 1982 to 2017 using the granger causality test, vector error correction model, and cointegration techniques. Findings from their study showed a bidirectional relationship between agricultural productivity and manufacturing industry output.

Uzoma, Odungweru \& Chukwuma - Ogbonna (2021) empirically examined the effect of foreign trade and external reserves in Nigeria from 1980 to 2019. Adopting the Vector Error Correction technique, their result showed that exchange rate had a significant negative impact on external reserves in Nigeria. Based on their findings, they therefore recommended that the CBN as the custodian of Nigeria's foreign reserves should stabilize the value of local currency taking into cognizance the external shocks that stem from exchange rate volatilities.

From the review of literature, it can be observed that previous studies focused on the contribution of agriculture to economic growth, macroeconomic performance and manufacturing industry output. To fill the existing gap in literature, this study extended the investigation of agricultural output to its contribution to foreign reserve in Nigeria.

\section{Methodology}

This study adopted quantitative techniques of analysis using time series data sourced from Central Bank of Nigeria (CBN) statistical bulletin from 1981 to 2019. The analysis started with a descriptive statistic test for all the variables. A stationarity test was further conducted on each variable using the Augmented Dickey-Fuller (ADF) test to check the existence (or otherwise) of a unit root in the model. This was followed by Johansen Co-integration test to analyze the presence of the long-run equilibrium relationship among the variables under study. The presence of co-integration premised the fitting of an error correction model, the purpose of which is to ascertain the speed of adjustment from the short-run equilibrium to the long-run equilibrium. In addition, to determine the direction of causality between the variables, the granger causality test was conducted. Finally, post estimation tests were carried out to determine the stability of the model. 
Also, post estimation tests were carried out

3.1 Model Specification

This study specified the linear below as:

FRSV $=$

f(AGRICOUTPUT)

To determine the relationship between agricultural output and foreign reserves, the former would be disaggregated into crop production, livestock, fishing and forestry. Introducing exchange rate and simplifying equation 1 , we have:

FRSV $=\mathrm{f}(\mathrm{CRPD}, \mathrm{LVST}$, FSHN, FRST, EXCR).

The econometric form of equation 2 is stated thus;

FRSVt $=\alpha 0+\alpha 1$ CRPD $t+\alpha 2$ LVST $t+\alpha 3$ FSHN $t+\alpha 4$ FRST $t+\alpha 5$ EXRt + et.

To minimize the scale effect inherent in data measurement, equation 3 is transformed to a loglinear form. This helps to interprete the estimated coefficients in terms of elasticities. The log linear form of equation 3 is therefore stated as follows:

LnFRSVt $=\alpha 0+\alpha 1 \ln$ CRPD $\mathrm{t}+\alpha 2 \ln \mathrm{LVST} \mathrm{t}+\alpha 3 \ln$ FSHN $\mathrm{t}+\alpha 4 \ln$ FRST $\mathrm{t}+\alpha 5$ EXR $t+$ et

Where:

FRSV $=$ foreign reserves

CRPD $=$ crop production

LVST $=$ livestock

FSHN $=$ fishing

FRST $=$ forestry

EXCR $=$ exchange rate of the naira to the US Dollar

$\alpha 0 \quad=$ Autonomous components of external reserve

$\alpha 1-\alpha 5=$ the slopes of crop production, livestock, fishing, forestry and exchange rate.

Ln = natural logarithm

$\mathrm{e} \quad=$ error term

$\mathrm{t}=$ time frame

On the a priori, it is expected that $\beta 1>0, \beta 2>0, \beta 3>0, \beta 4>0$, and $\beta 5><0$.

\section{Result and Discussion}

\section{Descriptive Statistics}

The summary of the descriptive statistics for the variables in the study are presented in the table below. 
142 | International Journal of Scientific and Management Research 4(4) 134-150

Table 1: Descriptive Statistics of variables

\begin{tabular}{|l|l|l|l|l|l|l|}
\hline Statistics & FRSV & CRPD & LVST & FSHN & FRST & EXR \\
\hline Mean & 18626.77 & 6122.366 & 554.9687 & 74.21974 & 166.2336 & 95.99657 \\
\hline Maximum & 53599.28 & 27645.81 & 2156.450 & 293.4200 & 987.5900 & 307.5000 \\
\hline Minimum & 224.4000 & 12.82000 & 2.530000 & 1.160000 & 0.540000 & 0.617700 \\
\hline Std. Dev. & 18289.34 & 7832.961 & 693.1112 & 91.95401 & 243.2504 & 95.79024 \\
\hline Skewness & 0.602656 & 1.182356 & 1.110930 & 1.061602 & 1.829881 & 0.851192 \\
\hline Kurtosis & 1.707147 & 3.286665 & 2.813420 & 2.739104 & 5.816079 & 2.900980 \\
\hline Jarque-Bera & 5.076897 & 9.220317 & 8.078645 & 7.436107 & 34.65176 & 4.725363 \\
\hline Probability & 0.078989 & 0.009950 & 0.017609 & 0.024281 & 0.000000 & 0.094167 \\
\hline Sum & 726444.2 & 238772.3 & 21643.78 & 2894.570 & 6483.110 & 3743.866 \\
\hline Observations & 39 & 39 & 39 & 39 & 39 & 39 \\
\hline Source: Resear & & & & & \\
\hline
\end{tabular}

Source: Researchers Computation Using E-Views 10

The result from the descriptive statistics in table 1 showed that foreign reserve, crop production, livestock, forestry, fishing and exchange rate averaged \$18.63billion, N841.4 billion, N2.8 billion, N4.7 billion, N339.9 billion and $\$ 96$ respectively. Foreign reserve grew to a maximum of $\$ 53.6$ billion with a standard deviation of $\$ 18.29$ billion. Crop production recorded a maximum value of N27.6 billion and a standard deviation value of N7.8 billion. Livestock grew to a maximum of N2.1 billion alongside a standard deviation value of N693.1 billion. Forestry recorded a maximum value of N293.4 billion coupled with a standard deviation of N91.95 billion. Fishing peaked at N987.6 billion with a standard deviation of N243.2 billion while the exchange rate of the naira to the US dollar recorded a maximum rate of N307.5 to a dollar at a standard deviation of $\$ 95.79$. The skewness statistics showed that all the variables were positively skewed, suggesting that their distributions have a long right tail. Furthermore, the kurtosis statistics of foreign reserves, livestock, forest and exchange rate were platykurtic, suggesting that their distributions were flatter than a normal distribution while that of crop production and fishing were leptokurtic suggesting otherwise.

\section{Unit Root Test}

This involves testing for the stationarity properties of the individual variables using the Augmented Dickey Fuller

(ADF) test to check for the existence of unit root in each of the time series. The results are presented in Table 4.2 below. 
143 | International Journal of Scientific and Management Research 4(4) 134-150

Table 2: Unit Root Result

\begin{tabular}{|l|l|l|l|l|l|}
\hline VARIABLE & ADF Test & $\begin{array}{l}1 \% \text { Critical } \\
\text { Value }\end{array}$ & $\begin{array}{l}5 \% \text { Critical } \\
\text { Value }\end{array}$ & $\begin{array}{l}10 \% \text { Critical } \\
\text { Value }\end{array}$ & $\begin{array}{l}\text { Order of } \\
\text { Integration }\end{array}$ \\
\hline FRSV & -5.631343 & -4.252879 & -3.548490 & -3.207094 & $\mathrm{I}(1)$ \\
\hline CRPD & -4.599666 & -4.226815 & -3.536601 & -3.200320 & $\mathrm{I}(1)$ \\
\hline LVST & -4.811126 & -4.309824 & -3.574244 & -3.221728 & $\mathrm{I}(1)$ \\
\hline FSHN & -5.974937 & -4.252879 & -3.548490 & -3.207094 & $\mathrm{I}(1)$ \\
\hline FRST & -3.373420 & -4.296729 & -3.568379 & -3.218382 & $\mathrm{I}(2)$ \\
\hline EXR & -5.337858 & -4.226815 & -3.536601 & -3.200320 & $\mathrm{I}(1)$ \\
\hline
\end{tabular}

Source: Researchers Computation Using E-Views 10

The unit root test reported in Table 2 above shows that none of the time series were stationary at ordinary level. The variables were therefore differenced to attain stationarity. Foreign reserves, crop production, livestock, fishing and exchange rate were stationary after first difference while forestry attained stationarity after second difference. In absolute terms, the ADF value of each of the variable was greater than the critical value at 5\%. Having confirmed the stationarity of the variables, it is therefore imperative to conduct the co-integration test using the Johansen procedure.

\section{Co-Integration Test}

The results of the co-integration test using the Johansen procedure are presented in the table below.

Table 3: Johansen Co-integration Test Results

\begin{tabular}{|l|l|l|l|l|l|}
\hline Eigen value & $\begin{array}{l}\text { Trace } \\
\text { Statistics }\end{array}$ & $5 \%$ critical value & $\begin{array}{l}\text { Eigen } \\
\text { value }\end{array}$ & $\begin{array}{l}\text { Max-eigen } \\
\text { Statistics }\end{array}$ & $\begin{array}{l}5 \% \\
\text { value }\end{array}$ \\
\hline 0.874143 & 234.3364 & 95.75366 & 0.874143 & 76.68639 & 40.07757 \\
\hline 0.847118 & 157.6500 & 69.81889 & 0.847118 & 69.48941 & 33.87687 \\
\hline 0.703683 & 88.16062 & 47.85613 & 0.703683 & 45.00402 & 27.58434 \\
\hline 0.611732 & 43.15660 & 29.79707 & 0.611732 & 35.00418 & 21.13162 \\
\hline 0.188553 & 8.152419 & 15.49471 & 0.188553 & 7.730633 & 14.26460 \\
\hline 0.011335 & 0.421786 & 3.841466 & 0.011335 & 0.421786 & 3.841466 \\
\hline
\end{tabular}

Source: Researchers Computation Using E-Views 10

The result of the co-integration in Table 3 was based on both the Trace Statistics and Maximum Eigenvalue. The results indicated four co- integrating equations at 5 percent significance level. 


\section{4 | International Journal of Scientific and Management Research 4(4) 134-150}

This suggests that there is a long run equilibrium relationship amongst the variables, foreign reserve, crop production, livestock, forestry, fishing and exchange rate in the estimated model. Given the existence of co-integrating equations, the requirement for fitting in an error correction model is satisfied.

\section{Parsimonious Error Correction Mechanism}

Co-integration deals with the methodology of modeling non-stationary time series variables (Iyoha and Ekanem, 2002). It is conducted based on the test proposed by Johansen (1991). In order to confirm the existence of a co-integrating vector among the variables, the ECM is employed. This is based on the general-to-specific rule and the results are presented on Table 4 below.

Table 4: Parsimonious ECM Result

\begin{tabular}{|l|l|l|l|l|}
\hline \multicolumn{2}{|l|}{ Dependent Variable: D(FRSV) } & & \\
\hline Variable & Coefficient & Std. Error & t-Statistic & Prob. \\
\hline C & -0.011320 & 0.005398 & -2.097041 & 0.0451 \\
\hline D(FRSV(-1)) & -0.145094 & 0.069876 & -2.076438 & 0.0460 \\
\hline D(FRSV (-2)) & -0.236096 & 0.138575 & -1.703736 & 0.0981 \\
\hline D(CRPD) & 0.186312 & 0.353013 & 0.527776 & 0.6027 \\
\hline D(LVST) & 0.006164 & 0.004458 & 1.382774 & 0.1755 \\
\hline D(FSHN) & -0.098162 & 0.075415 & -1.301623 & 0.2054 \\
\hline D(FRST) & -0.186312 & 0.353013 & -0.527776 & 0.6027 \\
\hline D(EXR) & -0.211941 & 0.102995 & -2.057789 & 0.0506 \\
\hline ECM(-1) & -0.236096 & 0.138575 & -1.703736 & 0.0981 \\
\hline R-squared & 0.429333 & Mean dependent var & 0.011196 \\
\hline Adjusted R-squared & 0.413028 & S.D. dependent var & 28.82989 \\
\hline S.E. of regression & 22.08777 & Akaike info criterion & 9.080463 \\
\hline Sum squared resid & 17075.43 & Schwarz criterion & 9.167540 \\
\hline Log likelihood & -165.9886 & Hannan-Quinn criter. & 9.111162 \\
\hline F-statistic & 26.33170 & Durbin-Watson stat & 1.972666 \\
\hline Prob(F-statistic) & 0.000011 & & \\
\hline Source: Researchers Computan & & & \\
\hline
\end{tabular}

Source: Researchers Computation Using E-Views 10

From the result in table 4 above, the R2 value of 0.429 implies that about 43 percent of the variation in foreign reserve is explained by crop production, livestock, forestry, fishery and 
exchange rate. Also, the overall regression result of the dynamic model was significant at 5 percent level as showed by the F-statistic of about 26.3. The Durbin Watson value of 1.97 shows that no autocorrelation exists in the model. The ECM was rightly signed and also significant at 10 percent level. The coefficient of -0.23 shows 23 percent speed of adjustment from the previous year to longrun equilibrium.

The coefficients of crop production and livestock in the current period were positive as expected theoretically but not statistically significant at conventional levels. The implication of this is that while crop production impacted foreign reserve positively, its impact was not meaningfully significant for the period covered by the study in Nigeria. The coefficient of fishery and forestry were however negative but also not statistically significant, contrary to a priori expectation. This implies that fishing and forestry activities retarded foreign reserves in Nigeria for the period covered by the study. This is consistent with the works of Nelson and Wilberforce (2018) who reported an insignificant relationship between external reserve and agricultural output in Nigeria. Exchange rate exerted a significant negative impact on external reserve in Nigeria. This is in line with the submission of Uzoma, Odungweru \& Chukwuma - Ogbonna (2021) who observed a negative relationship between exchange rate and external reserve in Nigeria.

\section{Causality Test}

The pairwise granger causality test was used to analyze the causal relationship between two variables in the model. The null hypothesis is rejected if the probability value is greater than 5 percent. On the flip side, if the probability value is less than 5 percent, we accept the null hypothesis of no causality. A unidirectional causality exists between two variables when either of the null hypothesis is rejected. Similarly, bi-directional causality occurs if both null hypotheses are rejected and no causality exists if neither of the null hypothesis is rejected. In this study, Granger causality test was conducted to find out the direction of causality between foreign trade and external reserve in Nigeria. 


\section{Table 5. Pairwise Granger Causality Tests}

Sample: 19812019

Lags: 2

\begin{tabular}{lcll}
\hline \hline Null Hypothesis: & Obs & F-Statistic & Prob. \\
\hline \hline CRPD does not Granger Cause FRSV & 37 & 3.71808 & 0.0353 \\
FRSV does not Granger Cause CRPD & & 4.29783 & 0.0222
\end{tabular}

\begin{tabular}{lccc}
\hline \hline LVST does not Granger Cause FRSV & \multirow{2}{*}{37} & $\begin{array}{l}0.97837 \\
1.78138\end{array}$ & $\begin{array}{l}0.3869 \\
\text { FRSV does not Granger Cause LVST }\end{array}$ \\
\hline \hline FSHN does not Granger Cause FRSV & 37 & 3.90394 & 0.0304 \\
FRSV does not Granger Cause FSHN & & 2.20635 & 0.1266 \\
\hline \hline FRST does not Granger Cause FRSV & 37 & 1.48807 & 0.2410 \\
FRSV does not Granger Cause FRST & & 1.17245 & 0.3226 \\
\hline \hline EXR does not Granger Cause FRSV & \multirow{2}{*}{37} & 4.52612 & 0.0186 \\
FRSV does not Granger Cause EXR & & 2.78647 & 0.0766
\end{tabular}

Source: Researchers Computationt Using E-Views 10

The result of the Pairwise Granger causality test in table 5 shows that a bi-directional causality exists between crop production and foreign reserves which is significant at 5 percent level. This is to say that crop production granger caused foreign reserves as foreign reserve granger caused crop production. Also, there was a bi-directional causality between exchange rate and foreign reserves at 10 percent level of significance. Fishing granger caused foreign reserves while foreign reserves did not granger because fishing. This implies that there exists a uni-directional causality from fishing to foreign reserves at 5 percent level of significance. Finally, no causality exists between livestock and foreign reserves as well as between forestry and foreign reserves at conventional levels of significance. 
147 | International Journal of Scientific and Management Research 4(4) 134-150
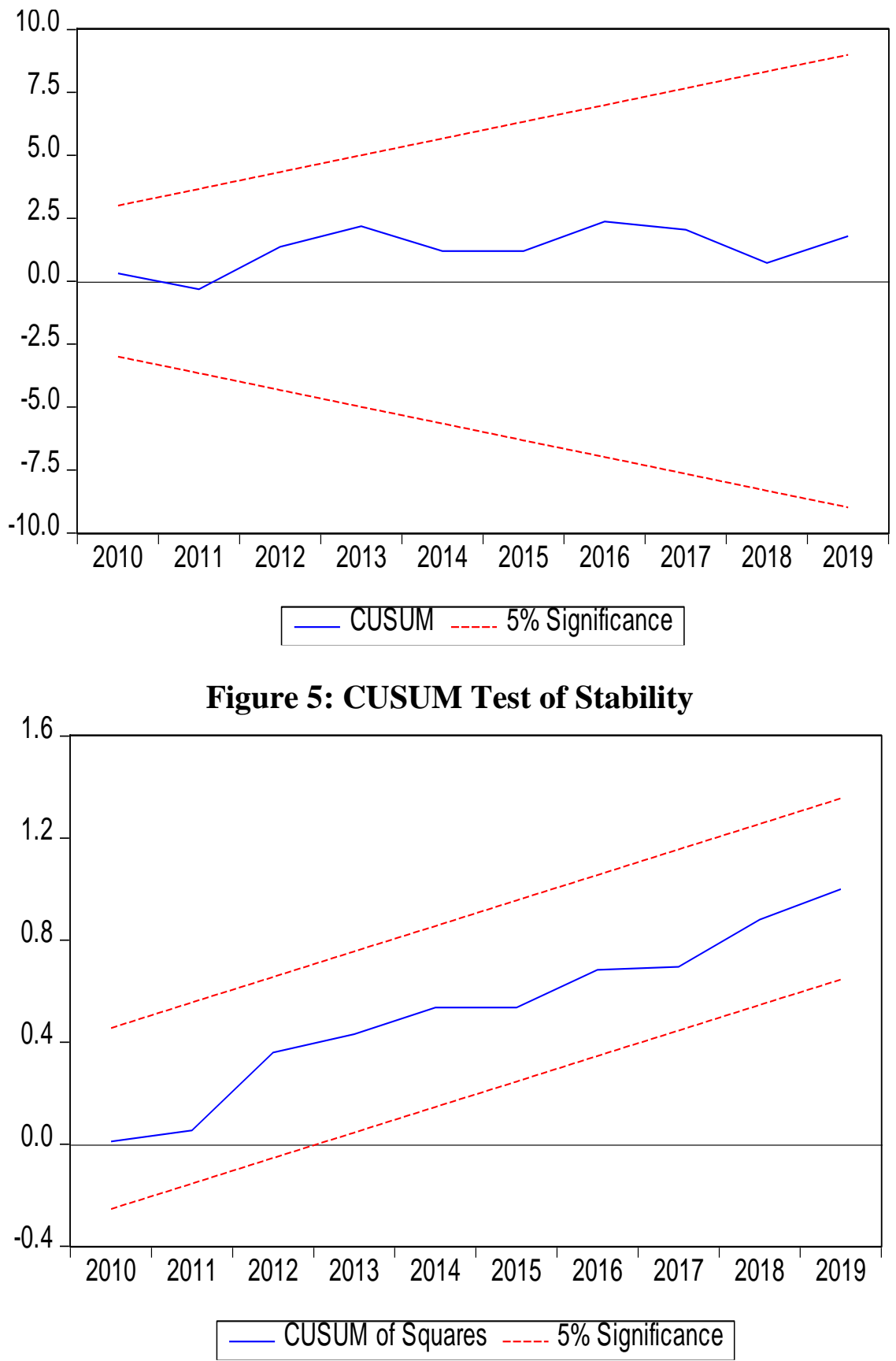

Figure 6: CUSUMSQ Test of Stability

An observation from the stability tests using the plots of the cumulative sum of recursive residuals (CUSUM) and cumulative sum of squares of recursive residual (CUSUMSQ) in figures 5 and 6 showed that they stayed within the 5 percent critical line, indicating the constancy or stability of the regression estimates throughout the period covered by the study.

\section{Conclusion and Policy Recommendations}


The study examined the effects of disaggregated agricultural output on foreign reserve in Nigeria between 1981 and 2019. Related studies on the subject matter were thoroughly reviewed. The Specific effects of agricultural output on foreign reserves from crop production, livestock, forestry, fishery and exchange rate was examined. Time series data were collected from the CBN statistical bulletin on the variables. The data were analyzed using unit root test, co-integration, error correction mechanism (ECM) technique and granger causality test to estimate the model. The Augmented Dickey-Fuller test showed that all the variables were integrated of order I (1). The Johansen cointegration test showed a stable long run relationship between the variables. The regression estimates from the error correction model showed that crop production had positive and insignificant effect on foreign reserves in Nigeria. Livestock, forestry and fishery however had negative and insignificant effects on foreign reserves in Nigeria for the period covered by the study. Exchange rate was observed to have impacted positively and significantly on external reserve in Nigeria within the period covered by the study. Furthermore, the granger causality test revealed that crop production and exchange rate had bi-directional causal relationships with foreign reserves while there was a uni-directional relationship between fishing and foreign reserves. Going by the findings from the study, the following recommendations were made. The first is that the federal government should channel part of its ownership of foreign reserve in form of recoveries, grants and bilateral cooperation to crop production in Nigeria as this has potentials of improving the reserves in the economy. Secondly, the central bank should give credit to those engaged in livestock, fishing and forestry activities from the portion of foreign reserve in its ownership. Finally, government policies should be geared towards improving agricultural output by simultaneously stabilizing the value of local currency in view of the external shocks that are associated with exchange rate volatilities.

\section{References}

1) Ake, C. (1996). Democracy and Development in Africa, Brookings Institution Press. Pg, 48.

2) Aminu, U. and Anono, A. (2012), 'An Empirical Analysis of the Contribution of Agriculture and Petroleum Sector to the Growth and Development of the Nigerian Economy,' International Journal of Social Science and Education, 2(4), 1-11.

3) Amao, O. D., Antwi M. A., Oduniyi, O. S., Oni, T. O. \& Rubhara, T. T. (2021). Performance of Agricultural Export Products on Economic Growth in Nigeria. Asian Journal of Agriculture \& Rural Development. 11(1), 47-52.

4) Central Bank of Nigeria $(\mathrm{CBN})$. Central Bank of Nigeria: Reserves Management. http://wwwcenbank.org/intops/reservesmgmt.asp retrieved25/6/2021.

5) Ehui, S. and Tsigas, M. (2009), 'The Role of Agriculture in Nigeria's Economic Growth: A General Equilibrium Analysis,' International Association of Agricultural Economists, August 16-22 August 2009, Beijing, China.

6) Etale, L. M., \&Ayunku, P. E. (2015). Effect of Agriculture Spending on Economic Growth in Nigeria: Empirical Evidence. Research Journal of Finance and Accounting. (IISTE); 6(2); 138-143. Niger Delta University, Bayelsa 
7) Ewetan, O O., and Okodua, H. (2013), 'Econometric Analysis of Exports and Economic growth in Nigeria,' Journal of Business Management and Applied Economics, 2(3), 1-14.

8) Eze, C. C., Onwube O., Ohalete. P. \& Ogbonna R. (2020). Nexus between Agricultural Output and Economic Growth in Nigeria. Nigerian Defence Academy Journal of Economics and Finance. 4(1), 184-195

9) Chang, J. J., Chen, B. \& Hsu, M. (2016). Agricultural Productivity and Economic Growth: Role of Tax Revenues an Infrastructures. Southern Economic Journal. 72(4), $891-914$.

10) Matsuyama, K. (1992). Agricultural Productivity, Comparative Advantage, and Economic Growth. Journal of Economic Theory. 58(2), 317-334, December.

11) Nelson, J. \& Wilberforce J. (2018). The relationship between external reserves and economic growth in Nigeria (1980-2016). International Journal of Economics, Commerce and Management. 6(5), 213-241.

12) Omekwe, S. O. P., Bosco, I. E., \& Obayori, J. B. (2018). Determinants of Agricultural Output in Nigeria. International Journal of Science and Management Studies. 1(4), 65-73.

13) Odetola, T. and Etumnu, C. (2013), 'Contribution of Agriculture to Economic Growth in Nigeria, International Food Policy Research Institute (IFPRI), Abuja, Nigeria,' Proceedings of The 18th Annual African Econometric Society (AES), 2013, at the session organized by the Association for the Advancement of African Women Economists (AAAWE), Accra, Ghana

14) Olajide, O, Akinlabi, B. and Tijani, A. (2012). Agricultural Resource and Economic Growth in Nigeria European Scientific Journal, 8(22), 103-115.

15) Osabohien, R., \& Osuagwu, E. (2017, May 7-9). Social protection policies and agricultural output in Nigeria: Empirical investigation using household survey data [Paper presentation]. 4th Covenant University International Conference on E-Governance in Nigeria (CUCEN), Ota, Nigeria.

16) Osuagwu, E. S., \& Olaifa, E. (2018). Effects of oil spills on fish production in the Niger Delta. PLOS ONE, 13, Article e0205114. http://doi.org/10.1371/journal.pone.0205114

17) Oyaniran, Taiwo AFCFTA work shop, 2020, current state of agriculture and agribusiness sector

18) World Bank, (2014). World Bank Development Report.

19) Sekunmade, A. (2009). The effects of petroleum dependency on agricultural trade in Nigeria: An error correlation modeling (ECM) approach. Scientific Research and Essay, 4(11), 1385-1391 
20) Syed, W A, Muhammad, A., and Rana, M. (2015), 'Agricultural Export and Economic Growth: A Case Study of Pakistan,' International Journal of African and Asian Studies, 13, 1-10.

21) Tuaneh, G. L. \& Okidim, A. I. (2019). On Agricultural Performance amidst Macroeconomic Instability in Nigeria; Autoregressive Distributed Lagged Modelling (2010Q1-2017Q4). Asian Journal of Economics, Business and Accounting.10 (2), 1-13.

22) Uzoma, C. N., Odungweru, K. \& Chukwuma Ogbonna J. A. (2021). Foreign Trade and External Reserves in Nigeria. International Journal of Developing and Emerging Economies. 9(2), 1-16.

\section{Works Cited}

Uzoma Chidoka Nnamaka \& Okidim, Andrew Iboh. (2021). An Analysis of the Effects of Disaggregated Agricultural Output on Foreign. International Journal of Scientific and Management Research, 04(04), 134-150. doi:http://doi.org/10.37502/IJSMR.2021.4410 